\title{
Placental 5-Deiodinase Activity and Fetal Thyroid Hormone Economy Are Unaffected by Selenium Deficiency in the Rat
}

\author{
JEAN-PIERRE CHANOINE, SHARON ALEX, SCOTT STONE, SHIH LIEH FANG, IRINI VERONIKIS, \\ JACK L. LEONARD, AND LEWIS E. BRAVERMAN \\ Departments of Medicine, Nuclear Medicine, and Physiology, University of Massachusetts Medical Center, \\ Worcester, Massachusetts 01655
}

\begin{abstract}
In adult male rats, selenium deficiency results in a near complete loss in the selenoprotein 5'deiodinase in the liver, resulting in decreased peripheral deiodination of thyroxine (T4) and increased serum T4 concentrations. Serum 3,5,3'-triiodothyronine concentrations are normal or slightly decreased, and serum $3,3^{\prime}, 5^{\prime}$ triiodothyronine concentrations are normal or slightly increased in selenium-deficient rats. We now report the effects of selenium deficiency on maternal and fetal thyroid hormone economy and on placental 5-deiodinase activity in the rat. Weanling female rats were fed either a seleniumdeficient or selenium-supplemented diet for 4 wk before mating and then throughout gestation. Rats were killed at $21 \mathrm{~d}$ of gestation. Selenium deficiency was confirmed by a 95 and $94 \%$ decrease in glutathione peroxidase and a 84 and $56 \%$ decrease in liver type I outer ring $5^{\prime}$ deiodinase activity in the mother and the fetus, respectively. In contrast to the increase in circulating $\mathrm{T} 4 \mathrm{observed}$ in seleniumdeficient male and nonpregnant female adult rats, serum T4 was not affected by selenium deficiency in pregnant rats, but there was a 3-fold increase in serum 3,3',5'triiodothyronine concentrations associated with a $70 \%$ decrease in maternal brain type II outer ring $5^{\prime}$ deiodinase activity. Maternal serum 3,5,3'-triiodothyronine concentrations were decreased by $21 \%$. Placental 5-deiodinase activity was unaffected by selenium deficiency. In the fetus, serum $\mathrm{T} 4,3,3^{\prime}, 5^{\prime}$-triiodothyronine, and TSH concentrations were not affected by selenium deficiency. These data suggest that placental 5-deiodinase is not a selenoenzyme and that the failure of selenium deficiency to increase serum $\mathbf{T} 4$ concentrations in the mother as well as the minor role played by liver type $I$ outer ring $5^{\prime}$ deiodinase in the fetus results in the protection of fetal thyroid hormone economy against the potentially deleterious effects of selenium deficiency. (Pediatr Res 34: 288-292, 1993)
\end{abstract}

\section{Abbreviations}

T4, thyroxine

rT3, 3,3', 5' -triiodothyronine

T3, 3,5,3'-triiodothyronine

$5^{\prime}$ D-I, type I outer ring $5^{\prime}$ deiodinase

$5^{\prime}$ D-II, type II outer ring $5^{\prime}$ deiodinase

Received December 8, 1992; accepted April 2, 1993.

Correspondence and reprints requests: Dr. Lewis E. Braverman, Division of Endocrinology and Metabolism, University of Massachusetts Medical School, 55 Lake Avenue North, Worcester, MA 01655.

Supported by NIH Grants DK 18919 (L.E.B.) and DK 38772 (J.L.L.), and by a grant from NATO. J.-P.C. is a recipient of a Public Health Service Fogarty International Research Fellowship (1 FO5 TW04373-01) and Aspirant at the "Fonds National de la Recherche Scientifique," Belgium.

\author{
DTT, dithiothreitol \\ PTU, 6-n-propyl-2-thiouracil \\ RIA, radioimmunoassay
}

T4 is a prohormone secreted only by the thyroid gland but has little biological activity unless it is deiodinated in the outer ring $\left(5^{\prime}\right)$ to generate T3. Two isozymes catalyze this reaction. $5^{\prime} \mathrm{D}-\mathrm{I}$ is present mainly in the thyroid, liver, and kidney; is sensitive to PTU (1); and contains the amino acid selenocysteine (2). In nonthyroidal tissues, $5^{\prime} \mathrm{D}-\mathrm{I}$ activity is increased in thyrotoxic rats and decreased in hypothyroid rats. 5'D-II is abundant in the brain, pituitary, and brown adipose tissue; is unaffected by PTU (1); and is not a selenoprotein $(3,4)$. Brain $5^{\prime} \mathrm{D}-\mathrm{Il}$ is decreased in thyrotoxic rats, increased in hypothyroid rats, and is downregulated by rT3 (5).

Endemic goiter and its most serious complication, endemic cretinism, are closely associated with severe iodine deficiency. Two forms of endemic cretinism have been described and have a variable geographical distribution (6). Myxedematous cretinism results from severe thyroid failure occurring during fetal or early postnatal life, whereas neurologic cretinism is characterized by subnormal growth and thyroid function, mental retardation, deaf mutism, spastic diplegia, and ataxic gait. Vanderpas et al. (7) recently suggested that the combined iodine and selenium deficiency they observed in an endemic area of Central Africa might play a role in the very high prevalence of the myxedematous form of cretinism most common in this area. They postulated that selenium deficiency, through a decrease in thyroid glutathione peroxidase activity, might be responsible for more exposure of the stimulated thyroid gland to toxic derivatives of oxygen and, therefore, play a role in the destruction of the gland and the predominant hypothyroidism observed in this type of cretinism (8). However, the recent identification of the type I iodothyronine deiodinase as a selenoprotein suggests that the relationship between selenium and thyroid hormone metabolism may be more complex (9). Thus, selenium supplementation alone to children with selenium and iodine deficient endemic goiter lowered serum T4 values because of restoration of 5'D-I activity, especially in children with cretinism (10).

In adult male rats fed a selenium-deficient diet for $5 \mathrm{wk}$, serum T4 concentrations are markedly increased, but there is little or no change in serum T3 concentrations. Serum rT3 concentrations are not affected by selenium deficiency $(4,11)$. The consistent 40 to $50 \%$ increase in circulating $\mathrm{T} 4$ is a consequence of the near complete loss of the selenoprotein 5'D-I in liver and kidney $(9,11)$, resulting in decreased peripheral T4 metabolism and prolonged T4 biologic half-life (12). We have recently shown that the maintenance of nearly normal serum $\mathrm{T} 3$ concentrations 
observed in selenium-deficient rats in the absence of peripheral $\mathrm{T} 4$ to $\mathrm{T} 3$ conversion is mainly due to thyroid secretion of T3, which accounts for at least $55 \%$ of circulating T3 in the rat (13). Moreover, in contrast to the near complete loss in hepatic selenium content and 5'D-I activity observed in selenium-deficient animals, selenium stores are decreased by only $27 \%$ and 5 'D-I activity is increased by $25 \%$ in the thyroid gland, suggesting that preserved and enhanced intrathyroidal T4 to T3 conversion by $5^{\prime} \mathrm{D}-\mathrm{I}$ might account for a large portion of the thyroidal contribution to circulating T3 (13). Despite the fact that 5'D-II is not a selenoprotein, $5^{\prime} \mathrm{D}$-II activity is also decreased in selenium-deficient rats, and we have shown that this decrease is caused directly by the increased circulating T4 present in these rats (4).

In pregnant rats, thyroid hormone economy of the feto-maternal unit is made more complex by the presence of the placenta, a tissue rich in inner ring 5 deiodinase, converting T4 into the biologically inactive metabolite rT3 (14). Placental deiodinase is insensitive to PTU and to variations in maternal thyroid status (15). Whether placental 5-deiodinase activity is affected by changes in selenium intake is unknown, but in a recent report, Santini et al. (16) were unable to label placental deiodinase with radioactive selenium in pregnant rats in vivo, suggesting that this enzyme does not contain selenium.

In this study, we determined the effects of selenium deficiency on maternal and fetal thyroid hormone economy and on placental 5-deiodinase activity in the rat $1 \mathrm{~d}$ before delivery. The data demonstrate that in the pregnant dam, in contrast to what is observed in the nonpregnant female, selenium deficiency does not affect circulating $\mathrm{T} 4$ but results in a marked increase in circulating rT3 concentrations. Fetal thyroid function and placental deiodinase activity are unaffected by selenium deficiency.

\section{MATERIALS AND METHODS}

The study was approved by the Animal Research Committee and complies with the institutional assurance certificate of the University of Massachusetts Medical Center. Weanling SpragueDawley rats ( 40 to $50 \mathrm{~g}$ ) supplied by Charles River Laboratories (Wilmington, MA) were fed a torula yeast-based semisynthetic diet (Teklad Premier, Madison, WI). The selenium-deficient diet (no. TD 86298) contained $5 \mu \mathrm{g} / \mathrm{kg}$ selenium; the marginally selenium-deficient diet was the same diet plus $25 \mu \mathrm{g} / \mathrm{kg}$ selenium (no. TD 91260); and the selenium-supplemented diet was the same diet plus $200 \mu \mathrm{g} / \mathrm{kg}$ selenium (no. TD 91259) as $\mathrm{Na}_{2} \mathrm{SeO}_{3}$. Rats were housed in stainless steel cages, and distilled water was available ad libitum. Body weight was monitored every other week. Mating was performed in our laboratory as previously described (17). On the evening of proestrus, as determined by vaginal smears, individual female rats were placed with a male (fed Purina Formulab Chow, Farm Exchange, Framingham, $\mathrm{MA}$ ) in the same cage. The next morning, the females were checked for cervical plugs, determining the 1 st $\mathrm{d}$ of pregnancy, and the male rat was removed.

Tissue homogenates. Tissue homogenates were prepared as follows. Aliquots of liver were homogenized in $4 \mathrm{vol}$ (wt/vol) 20 $\mathrm{mM}$ potassium phosphate buffer, $150 \mathrm{mM} \mathrm{NaCl}, \mathrm{pH} 7.4$ for determination of glutathione peroxidase activity and in 4 vol (wt/vol) of $250 \mathrm{mM}$ sucrose, $20 \mathrm{mM} \mathrm{N}$-2-hydroxyethylpiperazine- $N^{\prime}$-2-ethanesulfonic acid, $1 \mathrm{mM}$ EDTA, and $1 \mathrm{mM}$ DTT buffer, $\mathrm{pH} 7.0$, for determination of $5^{\prime} \mathrm{D}-\mathrm{I}$ activity. Cerebral cortex was homogenized in $4 \mathrm{vol}$ (wt/vol) of $320 \mathrm{mM}$ sucrose, $20 \mathrm{mM} N$-2-hydroxyethylpiperazine- $N^{\prime}$-2-ethanesulfonic acid, 1 mM EDTA, and $10 \mathrm{mM}$ DTT buffer, $\mathrm{pH} 7.0$, for determination of 5'D-II activity. The placentas from each dam were washed, pooled, and homogenized in $1 \mathrm{vol}(\mathrm{wt} / \mathrm{vol})$ of ice-cold $0.1 \mathrm{M}$ potassium phosphate buffer, 10 mM EDTA, pH 7.4. All samples were kept frozen at $20^{\circ} \mathrm{C}$.

Hormone assays and analytical procedures. Serum TSH was measured by RIA using materials obtained from the National Pituitary Agency, National Institutes of Health (Bethesda, MD). In adult pregnant and nonpregnant female rats, serum $\mathrm{T} 4$ and T3 concentrations were determined in duplicate by speciesadapted RIA using a single antibody technique with polyethylene glycol precipitation (18). Serum T4 concentrations in the selenium-supplemented and selenium-deficient male rats from a previous experiment were measured in the same assay as the current female rats. For determination of fetal serum T4 concentrations, serum was extracted with $2 \mathrm{vol}$ ( vol/vol) $95 \%$ ethanol and $2 \%$ ammonia to obtain sufficient $\mathrm{T} 4$ to measure accurately in the RIA. After centrifugation, the supernatant was evaporated and reconstituted with $0.09 \mathrm{M}$ barbital buffer, $\mathrm{pH}$ 8.6. Recovery was $89 \%$. Reverse T3 was measured by RIA using a kit obtained from Ciba-Corning (Medfield, MA). Serum rT3 concentrations also were measured in the sera of selenium-deficient and selenium-supplemented normal male rats from four separate previous experiments in the same assay as the current female rats. The binding of $\left[{ }^{125} \mathrm{I}\right] \mathrm{T} 4$ and $\left[{ }^{125} \mathrm{I}\right] \mathrm{T} 3$ to serum proteins was determined by vertical slab nondenaturing PAGE in phosphate buffer, $\mathrm{pH} 9.0$ (19) and the serum percent free T4 by equilibrium dialysis (20) as previously described. Free T4 was the product of the T4 and the percent free T4.

Glutathione peroxidase activity was determined from the oxidation of NADPH in the presence of $0.35 \mathrm{mM}$ 5-butyl hydroperoxide monitored spectrophotometrically at $340 \mathrm{~nm}$. Samples were run in duplicate, and results were expressed as nmol NADPH oxidized per min per $\mathrm{mg}$ protein (21). The $5^{\prime}$ deiodinase activities were determined by the release of radioiodide from 10 $\mu \mathrm{M}\left[{ }^{125} \mathrm{I}\right] \mathrm{rT} 3(\mathrm{sp} \mathrm{act}, 2175 \mathrm{Ci} / \mathrm{mmol}$ ) in the presence of $20 \mathrm{mM}$ DTT $\left(5^{\prime} \mathrm{D}-1\right)(22)$ or from $2 \mathrm{nM}\left[{ }^{125} \mathrm{I}\right] \mathrm{rT} 3$ in the presence of 20 $\mathrm{mM}$ DTT and $1 \mathrm{mM}$ PTU (5'D-II) (23). All samples were run in duplicate, and results were expressed as $U / \mathrm{mg}$ protein; $1 \mathrm{U}$ of enzyme activity represents the release of $1 \mathrm{pmol}^{125} \mathrm{I} / \mathrm{min}$ at $37^{\circ} \mathrm{C}$ $\left(5^{\prime} \mathrm{D}-\mathrm{I}\right)$ or $1 \mathrm{fmol}{ }^{125} \mathrm{I} / \mathrm{h}$ at $37^{\circ} \mathrm{C}\left(5^{\prime} \mathrm{D}-\mathrm{II}\right)$. Placental 5-deiodinase activity was determined from the percent of $\left[{ }^{125} \mathrm{I}\right] \mathrm{rT} 3$ generated from [ ${ }^{125}$ I]T4 as estimated by paper chromatography $(14,24)$. Values are reported as nmol [ $\left.{ }^{125} \mathrm{I}\right] \mathrm{rT} 3 / \mathrm{mg}$ protein/h. Protein was measured by the method of Bradford (25).

Experiments. Twenty weanling female rats were equally divided into a selenium-supplemented and a selenium-deficient group. The selenium-supplemented group received the seleniumsupplemented diet for $4 \mathrm{wk}$ before mating and throughout gestation. The selenium-deficient group received the marginally selenium-deficient diet for $2 \mathrm{wk}$, followed by the seleniumdeficient diet for $2 \mathrm{wk}$ before mating and throughout gestation. Dams were killed by decapitation on the 21 st d of gestation and exsanguinated. Maternal liver and cerebral cortex and placentas were collected. Immediately after collection of maternal blood, the abdomen was rapidly opened and amniotic fluid was obtained by amniocentesis from the amniotic sacs of several fetuses and combined into one pool for each litter. The fetuses were quickly delivered, decapitated, and the trunk blood from each fetus was collected and combined into one pool for each litter. Fetal liver and brain were collected and homogenized as described above.

In addition, weanling female $(n=21)$ rats, used as nonpregnant controls, were fed either a selenium-supplemented or seleniumdeficient diet for $5 \mathrm{wk}$, at which time blood and tissues were collected as described above.

Statistics. Unless otherwise noted, the results are expressed as mean \pm standard error. Statistical significance $(p<0.05)$ of differences between groups was determined using the two-tailed $t$ test for unpaired variates or for the nonparametric MannWhitney test (number of fetuses per litter in selenium-supplemented and selenium-deficient dams) (26).

\section{RESULTS}

As shown in Figure 1 (left panels), selenium deficiency resulted in the expected 95 and $86 \%$ decreases in maternal liver glutathi- 

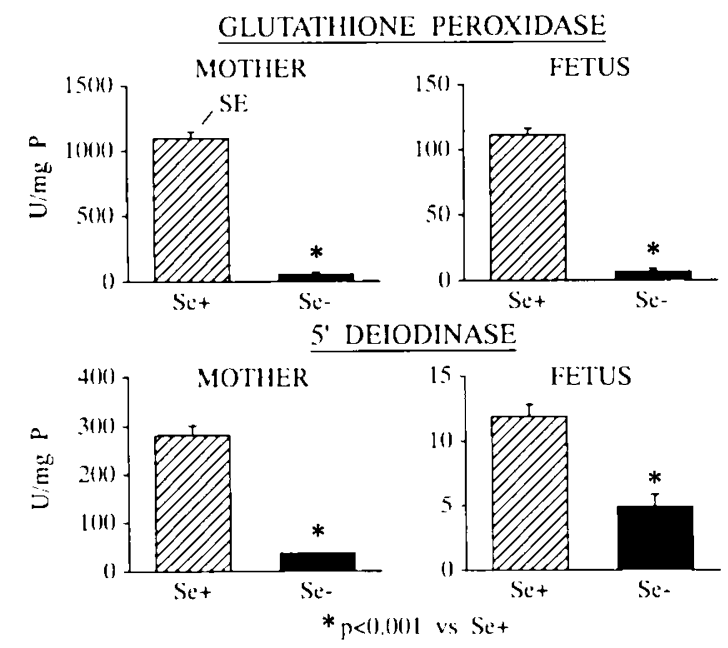

Fig. 1. Liver glutathione peroxidase (upper panels) and type I 5' deiodinase (lower panels) activities in selenium-supplemented $(\mathrm{Se}+)$ and selenium-deficient ( $\mathrm{Se}-$ ) mothers (left panels) and fetuses (right panels). Each value is the mean \pm standard error of 10 samples per group. ${ }^{*}, p<$ 0.001 compared with corresponding selenium-supplemented group.

Table 1. Serum thyroid hormone and TSII concentrations in selenium-supplemented and selenitum-deficient nonpregnant and pregnant female rats and their fetuses*

\begin{tabular}{llccc}
\hline & Diet & NP & P & Fetus \\
\hline T4 (nM) & Se+ & $49.1 \pm 3.3$ & $20.4 \pm 1.6$ & $6.2 \pm 0.4$ \\
& Se- & $60.4 \pm 3.9 \dagger$ & $20.2 \pm 2.5$ & $5.7 \pm 0.5$ \\
T3 (nM) & Se+ & $1.4 \pm 0.08$ & $1.0 \pm 0.06$ & ND \\
& Se- & $1.3 \pm 0.06$ & $0.8 \pm 0.07 \dagger$ & ND \\
TT3 (pM) & Se+ & $65.0 \pm 6.2$ & $33.4 \pm 6.4$ & $1653 \pm 193$ \\
& Se- & $80.0 \pm 11.2$ & $108.7 \pm 19.8 \ddagger$ & $1525 \pm 58$ \\
TSH (mU/L) & Se+ & $43.5 \pm 2.0$ & $58.3 \pm 4.1$ & $42.5 \pm 3.6$ \\
& Se- & $50.0 \pm 2.4$ & $47.7 \pm 3.8$ & $40.7 \pm 2.4$ \\
\hline
\end{tabular}

* Values are the mean \pm standard error $(n=10$ or 11$)$. NP, nonpregnant; $\mathrm{P}$, pregnant; $\mathrm{Se}+$, selenium-supplemented: $\mathrm{Se}-$, selenium-deficient: $\mathrm{ND}$, not detectable in fetal rats.

$\dagger p<0.05$.

$\ddagger p<0.001$, compared with corresponding $\mathrm{Se}+$ group.

one peroxidase and 5'D-I activities, respectively, compared with the values observed in the selenium-supplemented rats. Similarly (Fig. 1, right panels), liver glutathione peroxidase 5'D-I activities were decreased by 94 and $56 \%$, respectively, in the fetus, confirming selenium deficiency. Note the physiologically low hepatic 5 'D-I activity in the near-term rat fetus. Selenium deficiency did not affect maternal body weight $(380 \pm 7$ versus $388 \pm 8 \mathrm{~g})$ or thyroid weight $(25.9 \pm 0.6$ versus $25.2 \pm 0.4 \mathrm{mg})$ at the time the rats were killed or the number of fetuses per litter [median (range): $12.5(11-17)$ versus $13.5(10-16)$ ] in selenium-supplemented and selenium-deficient rats, respectively.

In female, nonpregnant rats, selenium deficiency resulted in a significant $86 \%$ decrease in liver $5^{\prime} \mathrm{D}-\mathrm{I}$ activity compared with the values observed in the corresponding selenium-supplemented, nonpregnant rats $(p<0.001)$.

Effect of selenium deficiency on thyroid function in pregnant and nonpregnant rats. As reported previously by us (17) and others (27), serum T4 concentrations were markedly lower in pregnant than in nonpregnant female rats $(p<0.001)$ (Table 1$)$. The reason for this difference remains unclear.

In the nonpregnant female rats, selenium deficiency caused a significant $26 \%$ increase in serum T4 concentrations but did not significantly affect serum T3, rT3, and TSH concentrations. In contrast, in pregnant rats, serum T4 concentrations were similar in selenium-supplemented and selenium-deficient animals. Moreover, there was a highly significant 3 -fold increase in serum
rT3 concentrations in selenium-deficient compared with selenium-supplemented pregnant rats. There was a significant $21 \%$ decrease in serum T3 concentrations in selenium-deficient compared with selenium-supplemented pregnant rats. There was no significant difference between serum free T4 concentrations $(20.6$ $\pm 2.7 \mathrm{pM}$ versus $20.3 \pm 4.0 \mathrm{pM}$ ), the percent [ $\left.{ }^{125} \mathrm{I}\right] \mathrm{T} 4$ bound to TTR $(69.5 \pm 2.8 \%$ versus $68.5 \pm 1.5 \%)$ and the percent $\left[{ }^{125}\right.$ I]T3 bound to albumin $(38.4 \pm 6.6 \%$ versus $48.6 \pm 4.0 \%)$ in seleniumsupplemented and selenium-deficient pregnant rats, respectively.

Finally, we observed a $70 \%$ decrease in cerebral cortex $5^{\prime} \mathrm{D}-\mathrm{II}$ activity in selenium-deficient $(20 \pm 6 \mathrm{U} / \mathrm{mg}$ protein) compared with selenium-supplemented $(65 \pm 12 \mathrm{U} / \mathrm{mg}$ protein) pregnant rats $(p<0.01)$.

Effect of selenium deficiency on fetal thyroid function. Fetal serum T4, rT3, and TSH concentrations were not affected by selenium deficiency (Table 1). There was no significant difference in brain 5'D-II activity between selenium-supplemented $(7.8 \pm$ $1.2 \mathrm{U} / \mathrm{mg}$ protein) and selenium-deficient fetuses $(6.9 \pm 1.2 \mathrm{U} /$ mg protein).

Effect of selenium deficiency on placental 5-deiodinase activity and amniotic fluid rT3 concentrations. As shown in Figure 2, maternal-fetal selenium deficiency had no effect on the activity of the placental 5-deiodinase enzyme. There was a significant $25 \%$ increase in amniotic fluid rT3 concentrations in seleniumdeficient rats $[1903 \pm 136$ versus $1599 \pm 89$ in selenium-supplemented rats $(p<0.05)]$.

Summary of effect of selenium deficiency on serum T4 and $r T 3$ concentrations in male rats, nonpregnant, and pregnant female rats, and term fotuses. Selenium deficiency resulted in a significant rise in serum T4 concentrations in male and nonpregnant female rats but had no effect in term pregnant and fetal rats (Fig. 3 ). In contrast, selenium deficiency resulted in a striking $325 \%$ increase in serum rT3 concentrations in the pregnant rat, no significant change in the term fetus and nonpregnant female rat, and a small increase in the male rat (no change in one experiment, nonsignificant increases in two experiments, and a significant increase in one experiment).

\section{DISCUSSION}

The present data demonstrate that, in contrast to what is observed in male and nonpregnant female rats, prolonged selenium deficiency in pregnant rats near delivery does not result in an increase in serum T4 concentrations but causes a marked increase in serum rT3 concentrations and that placenta 5-deiodinase activity and fetal thyroid economy are unaffected by selenium deficiency.

Selenium deficiency in adult male rats has been repeatedly shown to induce a 40 to $50 \%$ increase in serum T 4 concentrations with no or small increases in serum rT3 concentrations $(9,11$, 12). In the present study, these findings also are observed in adult nonpregnant female rats fed a selenium-deficient diet for $5 \mathrm{wk}$. The increase in circulating $\mathrm{T} 4$ is, however, less in the female

PI.ACENTAL 5 DEIODINASE
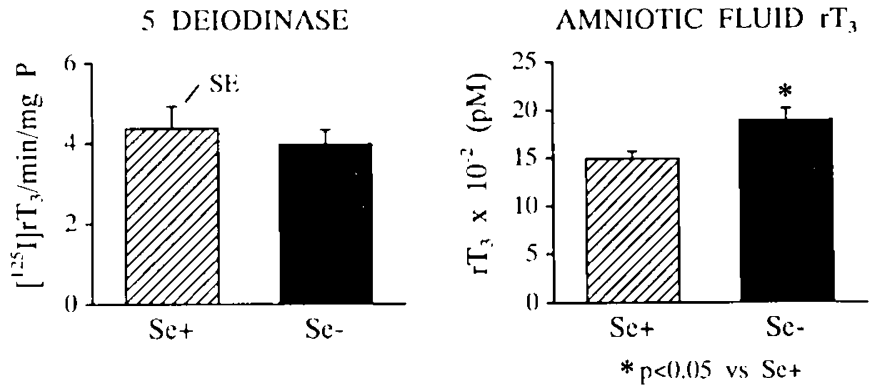

Fig. 2. Placental 5-deiodinase activity (left panels) and amniotic fluid rT3 concentrations (right pancls) in selenium-supplemented $(\mathrm{Se}+)$ and selenium-deficient $(\mathrm{Se}-)$ rats. Each value is the mean \pm standard error of 10 specimens per group. 

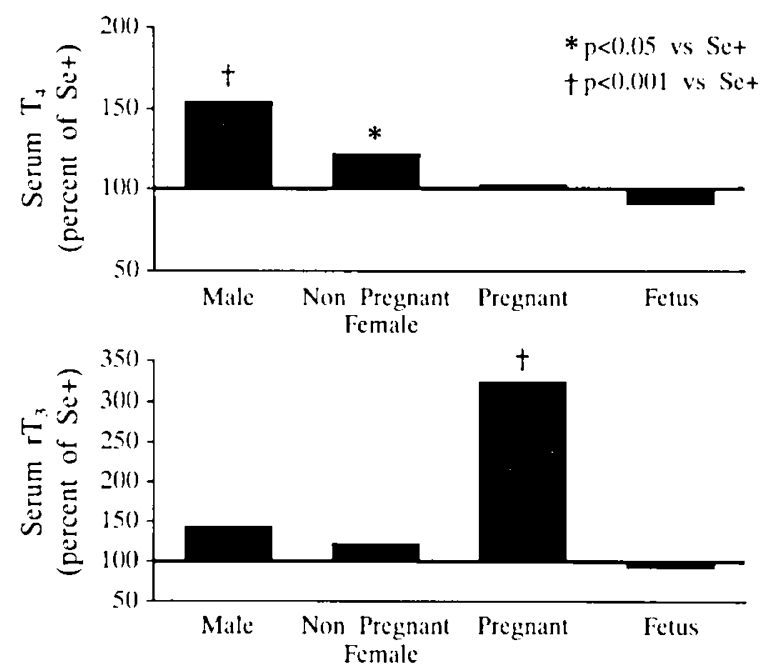

Fig. 3. Comparison of the effects of selenium deficiency on serum T4 and $\mathrm{rT} 3$ concentrations in adult male and female rats, in pregnant rats, and term fetal rats expressed as a percent of values in corresponding selenium-supplemented rats. The serum rT3 values in the male rats represent the mean percent increase in four experiments measured in the same assay as the sera from the female rats. There was no change in one experiment, a small but not significant increase in two experiments, and a significant increase in one experiment.

than in the male rats, suggesting the possibility of sex differences in the extrathyroidal deiodination of T4. In contrast, despite the marked decrease in the peripheral deiodination of T4 induced by selenium deficiency, selenium-deficient pregnant rats did not show the expected increase in serum $\mathrm{T} 4$ concentrations but established a striking three-fold increase in serum rT3 concentrations. A major difference between nonpregnant and pregnant rats near term is that pregnant rats have a placenta that is rich in inner ring or 5-deiodinase activity that converts T4 to rT3 and, as discussed below, placenta 5-deiodinase activity is unaffected by selenium deficiency. These data suggest that in the selenium-deficient pregnant rat, the expected increase in circulating $\mathrm{T} 4$ due to decreased $\mathrm{T} 4$ deiodination does not occur because the excess T4 is deiodinated to rT3 by the placenta, resulting in the maintenance of normal serum T4 concentrations. Also, in pregnancy, a small fraction of maternal T4 crosses the placenta to the fetus (28). Furthermore, because the rT3 generated in the placenta is not readily deiodinated in the seleniumdeficient pregnant rat as a result of near complete loss of hepatic $5^{\prime} \mathrm{D}$-I activity, a marked increase in maternal serum rT3 concentration occurs.

The 3-fold increase in serum rT3 concentrations in the pregnant rat was associated with a $25 \%$ increase in rT3 in the amniotic fluid but not in the fetal circulation, suggesting that maternal rT3 does not readily cross the placental barrier to the fetal compartment. Consistent with this data. El-Zaheri et al. (29) observed no increase in fetal serum rT3 and only a 2-fold increase in amniotic fluid rT3 concentrations despite the maintenance of maternal serum rT3 concentrations 36 times above control values by infusing rT3. The $25 \%$ increase in amniotic fluid $\mathrm{rT} 3$ concentration in selenium-deficient rats suggests that the substrate for amniotic fluid rT3 is T4 from the maternal circulation and that fetal thyroid function is not a determinant of amniotic fluid rT3. Consistent with the latter hypothesis, ElZaheri et al. (29) reported that amniotic fluid rT3 concentrations were markedly decreased in the presence of maternal but not fetal hypothyroidism.

In the present study, we observed a $70 \%$ fall in maternal brain 5'D-II activity. In selenium-deficient male rats, whose serum T4 concentrations are markedly increased because of decreased $5^{\prime} \mathrm{D}$ I activity, we have shown that the decrease in the activity and content of brain and pituitary 5'D-II, which is not a selenopro- tein, is due to enhanced $5^{\prime} \mathrm{D}-\mathrm{Il}$ turnover resulting directly from the increased circulating serum T4 values (4). In the present study, the marked decrease in brain 5' D-II activity in seleniumdeficient pregnant rats occurred in the presence of normal serum T4 concentrations. However, serum rT3 concentrations increased 3-fold, and it has been shown that rT3, as well as T4, regulates brain and pituitary $5^{\prime} \mathrm{D}$-II (5). Taken together, these data suggest that the chronic and marked increase in serum rT3 concentrations in the selenium-deficient pregnant rat results in a decrease in brain $5^{\prime} \mathrm{D}$-II activity and therefore in a potentially harmful decrease in brain T3 content.

The $21 \%$ decrease in serum T3 concentrations observed in the present study in selenium-deficient compared with seleniumsupplemented pregnant rats was associated with normal TSH concentrations. This contrasts with the data reported previously by us $(4,12)$ and others $(11,30)$ in adult male rats in whom decreased or unchanged serum T3 concentrations were associated with increased and unchanged serum TSH values, respectively, suggesting that serum T3 is an important factor in TSH regulation, as suggested by others $(31,32)$. However, in the present work, pregnant rats were studied, and attenuation of the negative feedback TSH response to low levels of circulating thyroid hormones has been reported during pregnancy (27).

Although we did not directly measure placental selenium content for technical reasons, the fact that both maternal and fetal hepatic glutathione peroxidase and 5'D-I activities were markedly decreased strongly suggests that the placenta, a tissue formed de novo, was also selenium deficient. Placental 5-deiodinase activity was not affected by selenium deficiency, indicating that placental 5-deiodinase is not a selenoprotein. These data are consistent with the recent results of Santini et al. (16) who found no evidence in the rat of a specific placental seleno-labeled protein after in vivo labeling of tissue selenoproteins with radioactive selenium during pregnancy. They also reported that aurothioglucose, a potent inhibitor of selenocysteine-containing enzymes, inhibits the placental deiodinase to a much lesser extent than the selenoprotein type I $5^{\prime}$ deiodinase.

In contrast to the marked changes observed in maternal thyroid hormone economy, selenium deficiency had no effect on fetal serum thyroid hormone and TSH concentrations. In the fetus, peripheral T4 to T3 conversion by the selenoenzyme 5'DI is physiologically very low, resulting in almost undetectable serum T3 concentrations. In contrast, inner ring 5 deiodination, mainly by the placenta (14) but possibly other fetal tissues (33). is active, resulting in the very high serum rT3 concentrations characteristic of the fetal period. Therefore, the further $55 \%$ decrease in liver 5'D-I that we observed in selenium-deficient compared with selenium-supplemented term fetuses is unlikely to significantly impair fetal thyroid hormone economy. Consistent with the maintenance of normal fetal serum T4 and rT3 concentrations, fetal brain 5'D-II activity and serum TSH were not affected by selenium deficiency.

In conclusion, the present study indicates that placental 5deiodinase activity is not affected by selenium deficiency, suggesting that it is not a selenoenzyme. The failure of selenium deficiency to increase serum T4 concentrations in the pregnant rat as well as the minor physiologic role played by the hepatic selenoenzyme $5^{\prime}$ deiodinase in the fetus results in protection of fetal thyroid hormone economy against the potentially deleterious effects of selenium deficiency.

\section{REFERENCES}

1. Leonard JL 1990 Identification and structure analysis of iodothyronine deiodinases. In: Greer MA (ed) The Thyroid Gland. Raven Press, New York, pp 285-305

2. Berry MJ, Banu L, Larsen PR 1991 Type I iodothyronine deiodinase is a selenium containing enzyme. Nature 349:438-440

3. Safran M, Farwell AP, Leonard JL 1991 Evidence that type II 5 '-deiodinase is not a selenoprotein. J Biol Chem 266:13477-13480

4. Chanoine JP, Safran M, Farwell AP, Tranter P, Ekenbarger DM, Dubord S, Alex S, Arthur JR, Becker GJ, Braverman LE, Leonard JL 1992 Selenium 
deficiency and type II $t^{\prime}$-deiodinase regulation in the euthyroid and hypothyroid rat: evidence of a direct effect of thyroxine. Endocrinology 131:479484

5. Silva JE, Leonard JL 1985 Regulation of rat cerebrocortical and adenohypophyseal type II 5'-deiodinase by thyroxine, triiodothyronine, and reverse triiodothyronine. Endocrinology 116:1627-1635

6. Delange FM 1991 Endemic cretinism. In: Braverman LE, Utiger RD (eds) Werner and Ingbar's The Thyroid. A Fundamental and Clinical Text. JB Lippincott Co, Philadelphia, pp 942-955

7. Vanderpas JB, Contempre B, Duale NL, Goosens W, Bebe N. Thorpe R, Ntambue K, Dumont J, Philly CH, Diplock AT 1990 Iodine and selenium deficiency associated with cretinism in northern Zaire. Am J Clin Nutr 52:1087-1093

8. Goyens P, Golstein J, Nsombola B, Vis H, Dumont JE 1987 Selenium deficiency as a possible factor in the pathogenesis of myxoedematous endemic cretinism. Acta Endocrinol 114:497-502

9. Arthur JR, Nicol F, Beckett GJ 1990 Hepatic iodothyronine 5'-deiodinase. The role of selenium. Biochem J 272:537-540

10. Contempre B, Dumont JE, Ngo B, Thilly CH, Diplock AT 1991 Effect of selenium supplementation in hypothyroid subjects of an iodine and selenium deficient area: the possible danger of indiscriminate supplementation of iodine-deficient subjects with selenium. J Clin Endocrinol Metab 73:213215

11. Beckett GJ, Beddows SE, Morrice PC. Nicol F, Arthur JR 1987 Inhibition of hepatic deiodination of thyroxine is caused by selenium deficiency in rats. Biochem J 248:443-447

12. Chanoine JP, Safran M, Farwell AP, Tranter P, Ekenbarger DM, Dubord S. Alex S, Stone S, Arthur JR, Beckett GJ, Braverman LE, Leonard JL 1992 Effects of selenium-deficiency on thyroid hormone economy in rats. Endocrinology 131:1787-1792

13. Chanoine JP, Braverman LE, Farwell AP, Safran M, Alex S, Dubord S, Leonard JL 1993 The thyroid gland is a major source of circulating T3 in the rat. J Clin Invest 91:2709-2713

14. Roti E, Fang SL, Braverman LE, Emerson CH 1982 Rat placenta is an active site of inner ring deiodination of thyroxine and 3,3',5-triiodothyronine. Endocrinology 110:34-37

15. Fay M, Roti E, Wright G, Braverman LE, Emerson CH 1984 Effect of propylthiouracil, iodothyronines and other agents on thyroid hormone metabolism in human placenta. J Clin Endocrinol Metab 58:280-286

16. Santini F, Chopra IJ, Hurd RE, Solomon DH, Chau Teco GN 1992 Study of the characteristics of the rat placental iodothyronine 5-monodeiodinase: evidence that it is distinct from the rat hepatic iodothyronine $5^{\prime}$-monodeiodinase. Endocrinology 130:2325-2332

17. Roti E, Braverman LE, Fang SL, Alex S, Emerson CH 1982 Ontogenesis of placental inner ring thyroxine deiodinase and amniotic fluid $3,3^{\prime}, 5^{\prime}$-trijodothyronine concentration in the rat. Endocrinology 111:959-963

18. DeVito WJ, Chanoine JP, Alex S, Fang S-L, Stone S, Huber CA, Shalhoub V, Lian JB, Stein GS, Braverman LE 1992 Effect of in vivo administration of recombinant acidic-fibroblast growth factor on thyroid function in the rat: induction of colloid goiter. Endocrinology 131:729-735

19. Young RA, Braverman LA, Rajatanavin R 1982 Low protein-high carbohydrate diet induces alterations in the serum thyronine-binding proteins in the rat. Endocrinology 110:1607-1612

20. Young RA. Danforth E, Vagenakis AP, Krupp PP. Frink R. Sims EAH 1979 Seasonal variation and the influence of body temperature on plasma concentrations and binding of thyroxine and triiodothyronine in the woodchuck. Endocrinology 104:996-999

21. Chada S, Whitney C, Newburger P 1989 Posttranscriptional regulation of glutathione peroxidase gene expression by selenium in the HL-60 human myeloid cell line. Blood 74:2535-2541

22. Leonard JL, Rosenberg IN 1980 Thyroxine 5 'deiodinase from rat kidney: substrate specificity and the $5^{\prime}$-deiodination of reverse triiodothyronine. Endocrinology 107:1376-1383

23. Visser TJ, Leonard JL, Kaplan MM, Larsen PR 1982 Kinetic evidence suggesting two mechanisms for jodothyronine $5^{\prime}$-deiodinase in rat cerebral cortex. Proc Natl Acad Sci USA 79:5080-5084

24. Roti E, Fang SL, Green K, Emerson CII. Braverman LE 1981 Human placenta is an active site of thyroxine and 3,3'.5-triodothyronine tyrosyl ring deiodination. J Clin Endocrinol Metab 53:498-501

25. Bradford MM $1976 \mathrm{~A}$ rapid and sensitive method for the quantitation of microgram quantities of protein utilizing the principle of protein-dye binding. Anal Biochem 72:248-254

26. Altman DG 1991 Practical Statistics for Medical Research. Chapman and Hall, London, pp 179-321

27. Calvo R, Obregon MJ, Ruiz de Ona C. Ferreiro B, Escobar del Rey F, Morreale de Escobar G 1990 Thyroid hormone economy in pregnant rats near term: a "physiological" animal model of non-thyroidal illness? Endocrinology 126:10-16

28. Calvo R, Obregon MJ, Escobar Del Rey F, Morreale de Escobar G 1992 The rat placenta and the transfer of thyroid hormones from the mother to the fetus. Effects of maternal thyroid status. Endocrinology 131:357-365

29. El-Zaheri MM, Vagenakis AG, Hinerfeld L, Emerson CH, Braverman LE 1981 Maternal thyroid function is the major determinant of amniotic fluid $3,3^{\prime}, 5^{\prime}$-triiodothyronine in the rat. J Clin Invest 67:1126-1133

30. Beckett GJ, MacDougall DA. Nicol F, Arthur F 1989 Inhibition of type I and type II iodothyronine deiodinase activity in rat liver, kidney and brain produced by selenium deficiency. Biochem J 259:887-892

31. Abend SL, Fang SL, Alex S. Braverman LE Leonard JL 1991 Rapid alteration in circulating free thyroxine modulates pituitary type II 5 '-deiodinase and basal TSH secretion in the rat. J Clin Invest 88:898-903

32. Emerson CH, Lew R, Braverman LE, DeVito WJ 1989 Serum thyrotropin concentrations are more highly correlated with serum triiodothyronine concentrations than with serum thyroxine concentrations in thyroid hormone infused thyroidectomized rats. Endocrinology 124:2415-2418

33. Huang TS, Chopra IJ, Boado R, Solomon DH, Chau Teco GN 1988 Thyroxine inner ring monodeiodinating activity in fetal tissues of the rat. Pediatr Res 23:196-199 